\title{
THINNING OF THE ICE SHEET IN MIZUHO PLATEAU, EAST ANTARCTICA
}

\author{
By Renji Naruse \\ (Institute of Low Temperature Science, Hokkaido University, Sapporo, Japan o6o)
}

\begin{abstract}
Surveys of a triangulation chain $250 \mathrm{~km}$ in length were carried out in December 1969 and December 1973-January 1974 along the surface contour lines from $2250 \mathrm{~m}$ to $2600 \mathrm{~m}$ in Mizuho Plateau, East Antarctica. Horizontal velocities were obtained as small values near the Yamato Mountains, while they had maxima of more than $20 \pm 0.7 \mathrm{~m} \mathrm{a}^{-1}$ around long. $39^{\circ} \mathrm{E}$., lat. $72^{\circ} \mathrm{S}$. in the drainage of the Shirase Glacier. Submergence velocities showed large values, such as $(0.7$ to $\mathrm{I}) \pm 0.25 \mathrm{~m} \mathrm{a}^{-1}$, in the region along lat. $72^{\circ} \mathrm{S}$. from long. $39^{\circ} \mathrm{E}$. eastward to long. $43^{\circ} \mathrm{E}$. The amount of snow accumulation there, of average thickness $0.2 \mathrm{~m} \mathrm{a}^{-1}$, was not enough to compensate for the deficit of the ice mass caused by the submergence flow. It follows that the ice sheet was thinning there. It is suggested that the ice sheet of Mizuho Plateau
\end{abstract} is in an unstable condition as a whole.

RÉsumé. Amincissement de la calotte glaciaire du Mizuho Plateau, Est Antarctique. On a réalisé la triangulation d'un cheminement de $250 \mathrm{~km}$ de long pendant l'été austral de 1969 et celui de $1973-74$ le long des lignes de niveau $2250 \mathrm{~m}$ à $2600 \mathrm{~m}$ sur le Mizuho Plateau dans l'Est Antarctique. Les vitesses horizontales trouvées étaient faibles près des Yamato Mountains tandis qu'elles présentaient leur maximum de plus de $20 \pm 0,7$ $\mathrm{m} \mathrm{a}^{-1}$ autour de $39^{\circ} \mathrm{E}$, $72^{\circ} \mathrm{S}$. Les vitesses verticales indiquent de forts affaissements tels que de o,7 à $\mathrm{I} \pm 0,25 \mathrm{~m} \mathrm{a}^{-1}$ dans la région du parallèle de $72^{\circ} \mathrm{S}$. entre $39^{\circ} \mathrm{E}$. à $43^{\circ} \mathrm{E}$. Le niveau d'accumulation de la neige en ce point $0,2 \mathrm{~m} \mathrm{a}^{-1}$ de l'épaisseur moyenne, n'était pas suffisant pour compenser le déficit de la masse de glace causé par l'écoulement vers le fond. Il s'en suit que la calotte glaciaire est ici en voie d'amincissement. On émet l'hypothèse que la calotte glaciaire de Mizuho Plateau toute entière est dans l'ensemble dans un état instable.

Zusammenfassung. Die Ausdünnung des Eisschildes auf dem Mizuho-Plateau, Ostantarktis. In den Südsommern I969 und 1973/74 wurde längs des 72 südl. Parallelkreises auf dem Mizuho-Plateau, Ostantarktis, eine Triangulationskette von $250 \mathrm{~km}$ Länge eingemessen. Nahe dem Yamato Mountains waren die Horizontalgeschwindigkeiten gering, während sie sum $39^{\circ} \mathrm{E}, 72^{\circ} \mathrm{S}$ Maximalwerte von über $20 \pm 0.7 \mathrm{~m}$ pro Jahr erreichten. Die Vertikalgeschwindigkeiten deuteten auf ein beträchtliches Absinken, wie etwa 0,7 bis $\mathrm{I} \pm \mathbf{0 , 2 5} \mathrm{m}$ pro Jahr im Gebiet längs des 72 . südl. Parallelkreises von $39^{\circ} \mathrm{E}$ ostwärts bis $43^{\circ} \mathrm{E}$. Die Menge der Schneeakkumulation in diesem Gebiet, die im Mittel o,2 m pro Jahr beträgt, reicht nicht zum Ausgleich des Massendefizits, das durch die Abtauchbewegung entsteht. Als Folge ergibt sich eine Ausdünnung des Eises. Es ist anzunehmen, dass der Eisschild auf dem Mizuho Plateau sich in seiner Gesamtheit instationär verhält.

\section{INTRODUCTION}

Some studies have been carried out in regard to the recent growth or shrinkage of the Greenland and the Antarctic ice sheets on the basis of the measurements of the ice flow. Federer and others (1970) obtained a mass deficit amounting to $0.1 \mathrm{~m} \mathrm{a}^{-1}$ (corrected later to $0.077 \mathrm{~m} \mathrm{a}^{-1}$ : Federer and Sury, 1976) during the ten years from I 959 to 1968 at Jarl-Joset Station on the Greenland ice sheet. Using their data, Nye (1975) discussed the resultant lowering of the ice-sheet surface. Meanwhile, it was suggested that the West Antarctic ice sheet is currently thinning (Hughes, I973; Weertman, I976; Thomas, I976) and is slightly thinning or stable (Whillans, 1973, I976, 1977). Thomas (1976) estimated that the Ross Ice Shelf is growing thicker by almost $\mathrm{I} \mathrm{m} \mathrm{a}^{-1}$ in the vicinity of its grounding line. More detailed information is much sought on the flow of the Antarctic ice sheet in the study of such dynamical problems. Direct measurements of the flow have, however, been very few, and have only been made intensively in limited regions near the coast or on the ice shelf.

A study on ice-sheet flow was one of the main subjects of the Japanese Glaciological Research Program (Shimizu, 1978) conducted from 1969-75 over the ice sheet of Mizuho Plateau, East Antarctica. For this study, during a period from 24 November to 30 December 1969, the traverse party of the roth Japanese Antarctic Research Expedition (JARE-ro) set up (first survey) a triangulation chain over a distance of $250 \mathrm{~km}$ in the inland region of Mizuho Plateau (Naruse and others, 1972). The second survey was carried out four years later during a period from 20 December I 973 to I6 January 1974 by JARE-14 (Naruse, 
1975[b]). The triangulation chain composed of 164 stations stretched along the parallel of latitude $72^{\circ} \mathrm{S}$., between Aoor at the south-east end of the Yamato Mountains and Ar64 at long. $43^{\circ}$ E. (see Fig. I). The surface elevation of the ice sheet increased gradually along the chain from $2250 \mathrm{~m}$ near Aoor to $2600 \mathrm{~m}$ near Ar64, so the chain was approximately parallel to a surface contour line. Obtained from the two surveys were horizontal and vertical

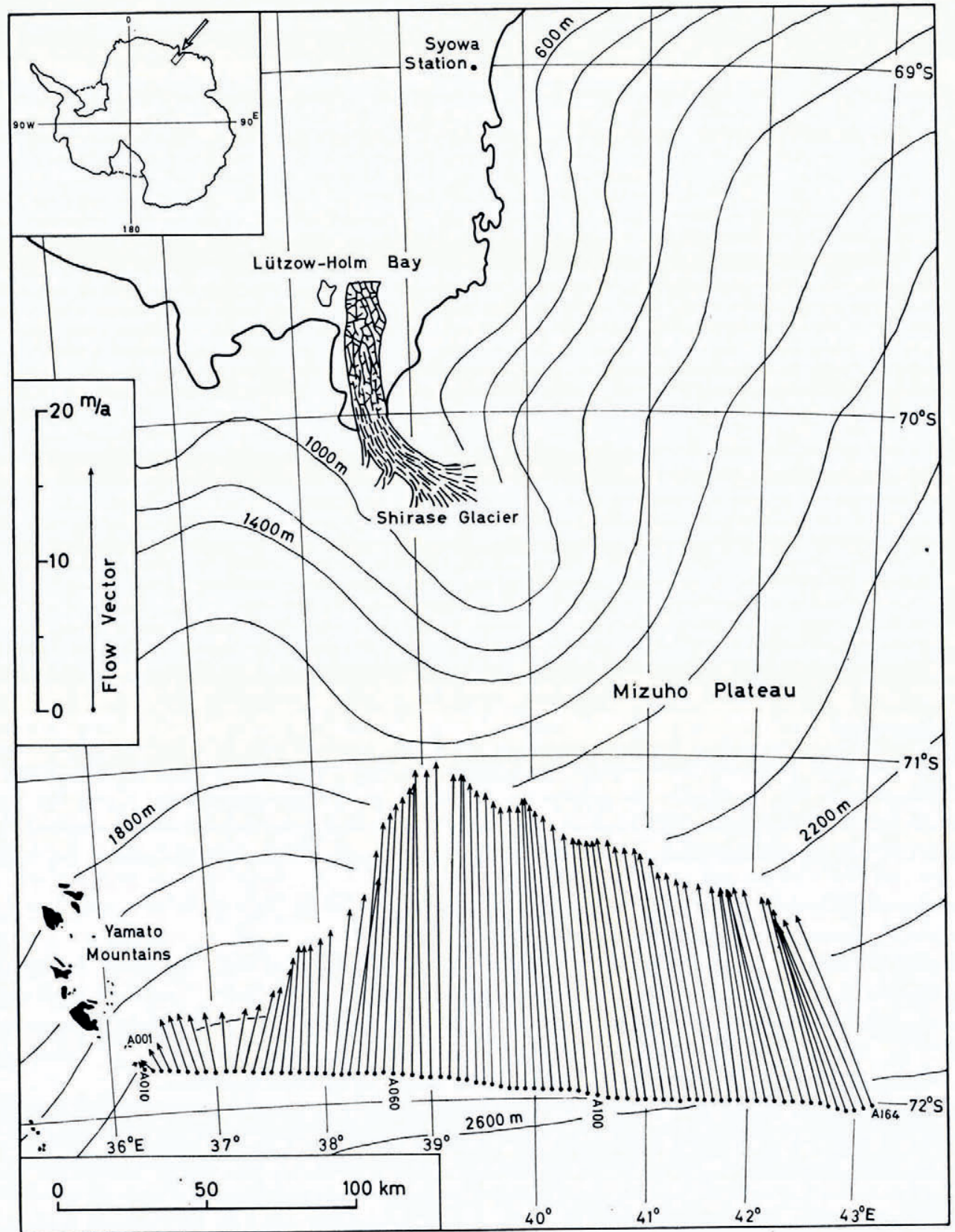

Fig. 1. Distribution of horizontal vectors of ice flow $\left(m a^{-1}\right)$ at every $5^{\prime}$ in longitude along the triangulation chain in Mizuho Plateau. Surface contours of the ice sheet are marked for every $200 \mathrm{~m}$. 
components of surface velocities at 140 points and also various parameters of surface strains in I 40 triangles of the chain. Some of these results were published in other articles (Naruse, 1978; Naruse and Shimizu, 1978; Mae and Naruse, 1978) with some discussions on the general flow and strain patterns and the dynamical features of the ice sheet in Mizuho Plateau. Measurements were also made along the chain of the surface slope (Naruse, 1975[b]), ice thickness (Shimizu and others, I972; Naruse and Yokoyama, I 975), gravity (Yoshida and Yoshimura, I972; Abe, 1975), and net accumulation (Yokoyama, I975).

The present paper reports chiefly a thinning phenomenon of the ice sheet deduced from the measurements of the vertical component of the surface flow velocity in Mizuho Plateau. The method of triangulation survey and some results from it are also briefly described.

\section{OUTLINE OF THE SURVEY OF A TRIANGULATION GHAIN AND DISTRIBUTION OF HORIZONTAL FLOW VEGTORS}

The datum point of a triangulation chain, Aoor, was selected upon a nunatak at lat. $71^{\circ} 47^{\prime} 28^{\prime \prime} \mathrm{S}$. and long. $36^{\circ} 12^{\prime}$ I $2^{\prime \prime}$ E., which belongs to the Yamato Mountains. Positions and elevations of all the triangulation stations were determined relative to their values at the datum point. The adopted elevation of this point was $2254 \mathrm{~m}$ obtained by the barometric method.

The triangulation chain was composed of ${ }_{1} 64$ stations. Each station was marked by a metal pole $3 \mathrm{~m}$ long or a bamboo stake $2.5 \mathrm{~m}$ long, which were used also as snow stakes. Both the first and the second survey of the chain were conducted principally by angle measurements with Wild $\mathrm{T}_{2}$ theodolites. Measurements were made of the horizontal angles of the three interior angles of all the constituent triangles, and the vertical angles from each station to four neighbouring stations. With the aim of correcting the accumulation of errors, the distance was measured with a radiowave distance meter (Cubic DM-20) and an azimuth was observed by shooting the sun for one side of every ro to i 5 triangles.

The geodetic coordinates and their mean-square errors (standard errors) were obtained at all the triangulation stations in 1969 and $1973^{-74}$ respectively, from the calculations by applying the least-squares method to a number of observation equations based on measured angles, azimuths, and distances. Then, the horizontal vector of ice movement was determined at each station from the difference between two geodetic positions. The surface elevations of the stations were obtained in 1969 and $1973-74$ respectively, by the measured values of vertical angles and the calculated distances from the above geodetic coordinates of the neighbouring two stations. Possible errors resulting from refraction due to the vertical gradient of air temperature and also from the curvature of the Earth can be counterbalanced, because measurements of vertical angles were carried out twice from both the stations in opposite directions and these were averaged. The "submergence or emergence velocity" $V_{z}$ was, then, calculated on the basis of the above two surface elevations, as described in the following section.

The results obtained for the three components of the surface velocity (namely the magnitude of the horizontal velocity $V_{\mathrm{h}}$, the azimuth $\alpha$ of $V_{\mathrm{h}}$ and the submergence or emergence velocity $V_{z}$ ) are shown in Table I, with calculated root-mean-square errors every ten stations along the chain. Since the surface flow is almost in a direction from south to north, the error in horizontal velocity was strongly controlled by the error involved in latitude, and not by the error in longitude. The absolute value of error in $V_{\mathrm{h}}$ showed a gradual increase from the datum point towards the end of the chain $\left(A_{1} 64\right)$; the relative error reached a minimum value of $3 \%$ at the middle part of the chain and 3 to $10 \%$ in other parts. Errors in azimuth are given as large values at places where the horizontal velocity is small. Relative errors in the submergence (emergence) velocity were considerably larger in the region from Aoo 3 to around Ao6o where the submergence (emergence) velocity was very small, while in the region eastward from Ao6o relative errors showed rather small values around $25 \%$. 
TABLE I. THREe components OF SURFACE VElocity OF ICE FloW AND THEIR ROOT-MEAN-SQUARE ERRORS AT EVERY TEN STATIONS OF A TRIANGULATION CHAIN

$\alpha$ : clockwise from the north point

$V_{z}$ : positive sign, submergence velocity; negative sign, emergence velocity

\begin{tabular}{|c|c|c|c|c|c|c|c|c|c|}
\hline \multirow[b]{2}{*}{ Station } & \multirow[b]{2}{*}{$\begin{array}{l}\text { Latitude } \\
\text { S. }\end{array}$} & \multirow[b]{2}{*}{$\begin{array}{c}\text { Longitude } \\
\text { E. }\end{array}$} & \multirow[b]{2}{*}{$\begin{array}{c}\text { Elevation } \\
\mathrm{m}\end{array}$} & \multicolumn{2}{|c|}{ Horizontal velocity } & \multicolumn{2}{|c|}{ Azimuth of velocity } & \multicolumn{2}{|c|}{ Submergence velocity } \\
\hline & & & & $\underset{\mathrm{m} \mathrm{a}^{-\mathbf{I}}}{V_{\mathrm{h}}}$ & $\begin{array}{c}\text { Error } \\
\mathrm{m} \mathrm{a}^{-1}\end{array}$ & $\stackrel{\alpha}{\operatorname{deg}}$ & $\begin{array}{c}\text { Error } \\
\text { deg }\end{array}$ & $\begin{array}{c}V_{z} \\
\mathrm{~m} \mathrm{a}^{-1}\end{array}$ & $\begin{array}{c}\text { Error } \\
\mathrm{m} \mathrm{a}^{-1}\end{array}$ \\
\hline Aoo5 & $71^{\circ} 4^{8^{\prime}} 24^{\prime \prime}$ & $36^{\circ} 16^{\prime} 13^{\prime \prime}$ & $228 I$ & 0.4 & \pm 0.03 & $34^{2}$ & \pm 6.2 & -0.09 & \pm 0.04 \\
\hline Aor 5 & $71^{\circ} 5^{1^{\prime}} 45^{\prime \prime}$ & $3^{\circ} 23^{\prime}$ 1 $8^{\prime \prime}$ & 2353 & I. I & \pm 0.1 I & 313 & \pm 5.8 & -0.07 & \pm 0.06 \\
\hline Ao25 & $71^{\circ} 50^{\prime} 3 I^{\prime \prime}$ & $36^{\circ} 47^{\prime} 42^{\prime \prime}$ & 2377 & $4 \cdot I$ & \pm 0.25 & 347 & \pm 5.2 & +0.02 & \pm 0.09 \\
\hline Ao35 & $71^{\circ} 53^{\prime} 12^{\prime \prime}$ & $37^{\circ} 12^{\prime}$ o $8^{\prime \prime}$ & 2423 & 4.5 & \pm 0.37 & 12 & 4 & +0.06 & \pm 0.11 \\
\hline Ao45 & $71^{\circ} 53^{\prime} 23^{\prime \prime}$ & $37^{\circ} 46^{\prime} 02^{\prime \prime}$ & 2399 & 9.0 & \pm 0.55 & 6 & \pm 5.4 & +0.15 & \pm 0.13 \\
\hline Ao55 & $71^{\circ} 54^{\prime} 28^{\prime \prime}$ & $3^{\circ} 18^{\prime} 39^{\prime \prime}$ & 2404 & 15.1 & \pm 0.64 & 9 & \pm 3.8 & +0.13 & \pm 0.15 \\
\hline Ao65 & $71^{\circ} 54^{\prime} 16^{\prime \prime}$ & $3^{8^{\circ}} 5^{6^{\prime}} 57^{\prime \prime}$ & 2382 & 20.4 & \pm 0.67 & I & \pm 3.0 & +0.71 & \pm 0.18 \\
\hline Ao75 & $71^{\circ} 55^{\prime} 18^{\prime \prime}$ & $39^{\circ} 23^{\prime} 45^{\prime \prime}$ & 24 II & 20.7 & \pm 0.73 & o & \pm 3.2 & +0.92 & \pm 0.20 \\
\hline Ao85 & $71^{\circ} 5^{6} 55^{\prime \prime}$ & $39^{\circ} 5^{I^{\prime}} 54^{\prime \prime}$ & 2442 & $19 \cdot 3$ & \pm 0.76 & 359 & \pm 3.5 & +0.78 & \pm 0.22 \\
\hline Aog5 & $71^{\circ} 56^{\prime} 54^{\prime \prime}$ & $40^{\circ} 25^{\prime} 53^{\prime \prime}$ & 2452 & 18.5 & \pm 0.80 & 354 & \pm 3.7 & +0.93 & \pm 0.23 \\
\hline Aro5 & $71^{\circ} 5^{8^{\prime}} 16^{\prime \prime}$ & $40^{\circ} 57^{\prime} 46^{\prime \prime}$ & 2482 & 17.5 & \pm 0.85 & $35^{2}$ & \pm 3.9 & +1.03 & \pm 0.25 \\
\hline AI 15 & $72^{\circ} 00^{\prime} 00^{\prime \prime}$ & $41^{\circ} 24^{\prime} 28^{\prime \prime}$ & 2510 & 16.6 & \pm 0.91 & $35^{\circ}$ & $\pm 4 \cdot 3$ & +1.02 & \pm 0.26 \\
\hline A1 25 & $7 \mathrm{I}^{\circ} 59^{\prime} 5 \mathrm{I}^{\prime \prime}$ & $4^{1^{\circ}} 43^{\prime} 07^{\prime \prime}$ & 2536 & 14.8 & $\pm 0.9^{2}$ & 349 & \pm 4.8 & +0.78 & \pm 0.27 \\
\hline Ar 35 & $71^{\circ} 59^{\prime} 43^{\prime \prime}$ & $42^{\circ}$ 10' $34^{\prime \prime}$ & 2524 & 14.4 & \pm 0.94 & $34^{8}$ & \pm 5.1 & +1.08 & \pm 0.28 \\
\hline Ar 45 & $71^{\circ} 57^{\prime} 59^{\prime \prime}$ & $42^{\circ} 33^{\prime} 5^{\prime \prime}$ & 2541 & 14.7 & \pm 0.97 & 343 & \pm 5.0 & +0.82 & \pm 0.29 \\
\hline 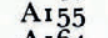 & $72^{\circ}$ or $1^{\prime} 24$ & $42^{\circ} 5^{\prime}, 04^{\prime \prime}$ & $25^{88}$ & I3.3 & \pm 0.99 & 341 & $\pm 5 \cdot 5$ & +0.77 & \pm 0.30 \\
\hline & & $09^{\prime} 4^{8^{\prime \prime}}$ & 2606 & I 3.6 & $\pm \mathbf{I . O I}$ & $33^{6}$ & \pm 5.2 & +0.04 & \pm 0.31 \\
\hline
\end{tabular}

The distribution of horizontal flow vectors $\left(\mathrm{m} \mathrm{a}^{-1}\right)$ across the triangulation chain every $5^{\prime}$ in longitude are shown by the thin arrows in Figure $\mathrm{I}$. It is clear that the flow is converging into the Shirase Glacier. Remarkable features noted of the horizontal flow along the parallel of latitude $72^{\circ} \mathrm{S}$. in Mizuho Plateau are as follows:

The flow velocity had very small values less than $2 \mathrm{~m} \mathrm{a}^{-1}$ and the flow direction was northwestward in the vicinity of the Yamato Mountains, namely the region to the west of long. $3^{\circ} 35^{\prime} \mathrm{E}$. The small value is considered to be caused by the effect of many nunataks lying down-stream. The direction of the flow was different on either side of long. $37^{\circ} \mathrm{E}$. To the west of the boundary, the flow had a westward component, while to the east of it, the flow had an eastward component. The macro-scale surface contours of the ice sheet showed a ridge there (Shimizu and others, 1978[b]). It must follow, therefore, that the ice divide exists near long. $37^{\circ} \mathrm{E}$. between the drainage of the Shirase Glacier and the drainage at its west side. The velocity increased gradually with the increase of distance from the datum point, that is from west to east. It was more than $20 \mathrm{~m} \mathrm{a}^{-1}$ in the region around long. $39^{\circ} \mathrm{E}$. The velocity then decreased slightly and reached ${ }_{1} 3.6 \mathrm{~m} \mathrm{a}^{-1}$ at $\mathrm{AI}_{1} 64$ which was located at the east end of the triangulation chain. The direction of the flow shifted gradually from northward to westward in the eastern part of the chain, and finally it was north-north-west at Ar64.

\section{Thinning Rate OF THE ICE SHEET ALONG THE GHAIN}

The submergence or emergence velocity $V_{z}$ of the surface flow can be obtained from

$$
V_{z}=V_{z}^{\prime}-V_{\mathbf{h}} \tan \theta
$$

where $V_{z}^{\prime}$ is the vertical velocity component of the top of a marker stake, $V_{\mathrm{h}}$ is the horizontal velocity and $\theta$ is the surface slope (positive sign) along the flow direction. As the value of $V_{z}^{\prime}$ is taken positive downward, a positive value of $V_{z}$ indicates a submergence velocity and a negative value indicates an emergence velocity. The quantity, $V_{z}-A$, gives the rate of change of the surface elevation per year, where $A$ is annual net accumulation in snow depth (positive value of $A$ shows accumulation; negative value ablation). We call the quantity, $V_{z}-A$, the thinning-rate of the ice sheet. 


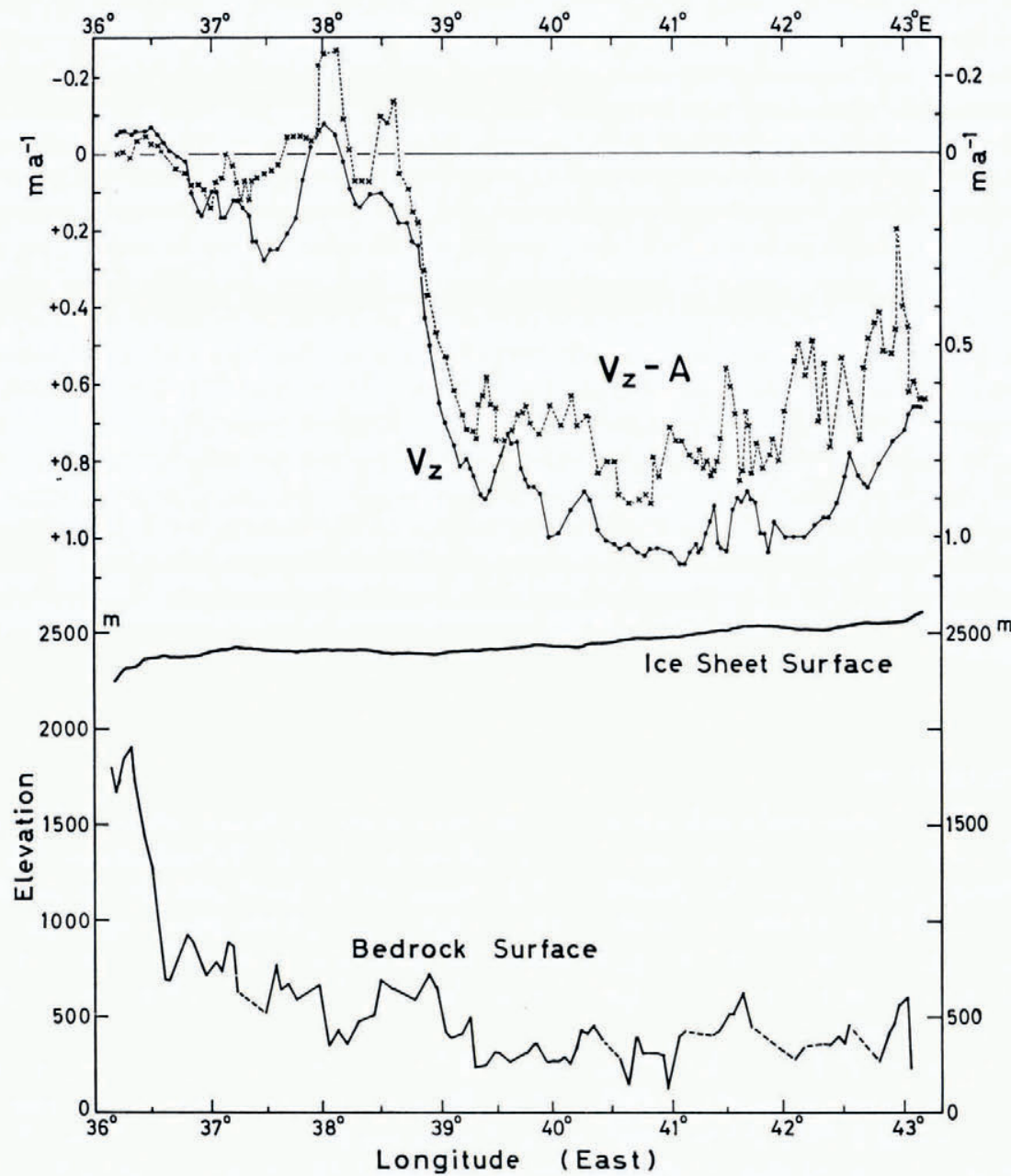

Fig. 2. Variations in submergence (emergence) velocity $V_{z}\left(m a^{-1}\right)$, thinning-rate $V_{z}-A\left(m a^{-1}\right)$, and profiles of the ice sheet and bedrock surfaces along the triangulation chain in $72^{\circ} S$. in Mizuho Plateau. Positive $V_{z}$ indicates submergence velocity; negative $V_{z}$ emergence velocity. Running mean over three stations was applied to $V_{z}$ and $V_{z}-A$. The bedrock profile was obtained from the results of radio echo-soundings and gravity measurements as well.

Figure 2 shows the submergence (emergence) velocity $V_{z}\left(\mathrm{~m} \mathrm{a}^{-1}\right)$ at the surface, the thinning rate $V_{z}-A\left(\mathrm{~m} \mathrm{a}^{-1}\right)$, and the surface and the bedrock profiles along the chain plotted against the longitude from $36^{\circ}$ Io' E., the south-east end of the Yamato Mountains, to long. $43^{\circ}$ I $0^{\prime}$ E. Annual net accumulation $A$ was obtained by averaging over four years from the measurements of snow stakes. The variations of $V_{z}$ and $V_{z}-A$ were slightly smoothed by using the running mean over three stations. The following results are characteristic in Figure 2:

(I) Negative velocities which signify emergence flow of ice were obtained in the limited regions around long. $36^{\circ} 30^{\prime} \mathrm{E}$. and $38^{\circ} \mathrm{E}$. The annual net accumulation was negative (mean value, $\left.-0.05 \mathrm{~m} \mathrm{a}^{-1}\right)$ in the former region near the Yamato Mountains, which represents 
ablation due mainly to sublimation of the exposed surface ice. A large number of meteorites were found (Yoshida and others, 1971 ; Shiraishi and others, 1976; Yanai, 1978; Matsumoto, 1978) in this region which, therefore, was named the Meteorite Ice Field. The bedrock profile is marked by the great rise there.

(2) In most parts except the above regions, positive $V_{z}$ indicative of submergence flow was observed. The value of $V_{z}$. increased suddenly near long. $39^{\circ} \mathrm{E}$. where the horizontal velocity was close to the maximum value (see Fig. I), and then it decreased gradually from long. $42^{\circ} \mathrm{E}$. eastward. The value of $V_{z}$ reached $1 \mathrm{~m} \mathrm{a}$-1 in the region between long. $40^{\circ} \mathrm{E}$. and $42^{\circ} \mathrm{E}$., where the mean-square errors of $V_{z}$ were from $\pm 0.25 \mathrm{~m} \mathrm{a}^{-1}$ to $\pm 0.30 \mathrm{~m} \mathrm{a}^{-1}$, as shown in Table $\mathrm{I}$.

(3) The amount of net accumulation $A$ showed remarkable variations from place to place. Observation of the surface topography revealed a strong correlation between $A$ and surface reliefs. Namely, the net accumulation was large in the depressed terrain (mean value, $0.47 \mathrm{~m} \mathrm{a}^{-1}$ ), small in the mounded terrain (mean value, $0.09 \mathrm{~m} \mathrm{a}^{-1}$ ), and average in the whole area is $0.20 \mathrm{~m} \mathrm{a}^{-1}$ in thickness of snow. Assuming the average density of the surface snow as $45^{\circ} \mathrm{kg} \mathrm{m}^{-3}$ (Naruse, 1975[a]; Watanabe, r975), the annual net accumulation was $90 \mathrm{~kg} \mathrm{~m}^{-2} \mathrm{a}^{-1}$ in the region along the chain except near the Yamato Mountains.

(4) The value of $V_{z}-A$ was close to $0 \mathrm{~m} \mathrm{a}^{-1}$ in the region from long. $39^{\circ} \mathrm{E}$. westward; while in the region eastward, it was a large value showing a considerable thinning-rate of about $0.7 \mathrm{~m} \mathrm{a}^{-\mathrm{I}}$.

\section{CONGLUding REMARKs}

Results of the present study indicated that the average submergence velocity was $0.9 \pm 0.25$ $\mathrm{m} \mathrm{a} \mathrm{a}^{-1}$ in the region from long. $39^{\circ} \mathrm{E}$. to $43^{\circ} \mathrm{E}$. along lat. $72^{\circ} \mathrm{S}$. Submergence flow is considered to have resulted from densification in the upper snow layer and also from outflow of ice from a vertical column with unit cross-sectional area through the thickness of the ice sheet. The rate of surface lowering due to densification of snow was estimated as about 0.1 to 0.2 $\mathrm{m} \mathrm{a}^{-1}$ from the calculations of the equation on the non-Newtonian densification of snow derived by Bader ( 1963$)$.

The distribution of $V_{z}-A$ shows that the supply of snow on the ice-sheet surface was insufficient to maintain a stable condition of the ice sheet in the region to the east of long. $39^{\circ} \mathrm{E}$. It is concluded that the ice sheet was shrinking along a part of the chain during this observation period, as estimated using a similar method in the West Antarctic ice sheet (Hughes, 1973; Whillans, I973; Thomas, I976). However, surface lowering was not necessarily taking place over the entire area of Mizuho Plateau. As for the entire ice in the drainage basin of the Shirase Glacier in Mizuho Plateau, Shimizu and others (1978[a]) discussed the mass budget. The following estimates were made from the measurements in 1969-75: the drainage area: $20 \times 10^{10} \mathrm{~m}^{2}$; the stored ice: $32 \times 10^{16} \mathrm{~kg}$ (Shimizu and others, $1978[\mathrm{~b}])$; the total accumulation rate: $\left(\mathrm{I}_{3} \pm 8\right) \times \mathrm{IO}^{\mathrm{I2}} \mathrm{kg} \mathrm{a}^{-1}$ (Yamada and Watanabe, $\left.\mathrm{I}_{978}\right)$; the annual discharge of ice through the Shirase Glacier: $(7.4 \pm 1.9) \times 10^{12} \mathrm{~kg} \mathrm{a}^{-1}$ (Nakawo and others, 1978$)$. Then, we obtained the mass budget of $(6 \pm 8) \times 10^{12} \mathrm{~kg} \mathrm{a}^{-1}$ by subtracting the discharge from the total accumulation, since the latter included the estimated amounts of melting at the coastal region and of the drifting snow. The mean value indicated a reasonably large positive budget. Therefore, it remains possible that the observed intense thinning of the ice sheet in the region from long. $39^{\circ} \mathrm{E}$. to $43^{\circ} \mathrm{E}$. along the parallel of latitude $72^{\circ} \mathrm{S}$. might be a rather local or recent occurrence. To elucidate the causes and mechanisms of the instability of the ice sheet, more knowledge is urgently called for especially as to the flow-rates along a flow line and also along a vertical direction, together with the thermal regime of the ice sheet, in East Antarctica. 


\section{Acknowledgements}

The author is deeply indebted to many members of the wintering parties of the Ioth and the I 4 th Japanese Antarctic Research Expedition led by Dr K. Kusunoki and Dr T. Hirasawa respectively, for generous support in the field. Special thanks are due to $\mathrm{Mr} \mathrm{H}$. Ando, Drs M. Yoshida, K. Omoto, Messrs Y. Ageta, S. Kobayashi, Y. Abe, K. Yokoyama, and K. Shiraishi for their co-operation with him in carrying out triangulation surveys. $\mathrm{He}$ also expresses his gratitude to Dr S. Mae of the National Institute of Polar Research, and Dr G. Wakahama and Dr T. Ishida of the Institute of Low Temperature Science, Hokkaido University for their useful comments on this paper.

\section{REFERENGES}

Abe, Y. 1975. Gravity data. (In Naruse, R., ed. Glaciological research program in Mizuho Plateau-west Enderby Land, East Antarctica. Pt. 3, 1973-1974. Tokyo, National Institute of Polar Research, p. 1 14-19. (Japanese Antarctic Research Expedition. JARE Data Reports, No. 28 (Glaciology).))

Bader, H. 1963. Theory of densification of dry snow on high polar glaciers. II. (In Kingery, W. D., ed. Ice and snow; properties, processes, and applications: proceedings of a conference held at the Massachusetts Institute of Technology, February $12-16$, 1962 . Cambridge, Mass., M.I.T. Press, p. 351-76.)

Federer, B., and Sury, H. V. von. 1976. Deducing thickness changes of an ice sheet: comments on the paper by J. F. Nye. Journal of Glaciology, Vol. 1 7, No. 77, p. 531. [Letter.]

Federer, B., and others. 1970. Outflow and accumulation of ice in Jarl-Joset Station, Greenland, [by] B. Federer, H. [V.] von Sury, K. Philberth, and M. [R.] de Quervain. Fournal of Geophysical Research, Vol. 75, No. 24, p. $4567-69$.

Hughes, T. J. 1973. Is the West Antarctic ice sheet disintegrating? Journal of Geophysical Research, Vol. 78, No. 33, p. 7884-910.

Mae, S., and Naruse, R. 1978. Possible causes of ice sheet thinning in the Mizuho Plateau. Nature, Vol. 273, No. 5660 , p. $291-92$.

Matsumoto, Y. 1978. Collection of Yamato meteorites, East Antarctica, in November and December 1975, and January 1976. (In Nagata, T., ed. Proceedings of the second Symposium on Yamato Meteorites. Tokyo, National Institute of Polar Research, p. 38-50. (Memoirs of National Institute of Polar Research. Special Issue No. 8.))

Nakawo [i.e. Nakao], M., and others. 1978. Discharge of ice across the Sôya coast, [by] M. Nakawo [i.e. Nakao], Y. Ageta, and A. Yoshimura. (In Ishida, T., ed. Glaciological studies in Mizuho Plateau, East Antarctica, 1969-1975. Tokyo, National Institute of Polar Research, p. 235-44. (Memoirs of National Institute of Polar Research. Special Issue No. 7.))

Naruse, R. I975[a]. Density and hardness of snow in Mizuho Plateau in 1969-1970. (In Shimizu, H., ed. Glaciological research program in Mizuho Plateau-west Enderby Land, East Antarctica. Pt. 2, 1969-1973. Tokyo, National Institute of Polar Research, p. 180-86. (Japanese Antarctic Research Expedition. JARE Data Reports, No. 27 (Glaciology).))

Naruse, R. ${ }_{1975}$ [b]. Movement of the ice sheet observed by a triangulation chain. (In Naruse, R., ed. Glaciological research program in Mizuho Plateau - west Enderby Land, East Antarctica. Pt. 3, I973-1974. Tokyo, National Institute of Polar Research, p. 48-61. (Japanese Antarctic Research Expedition. JARE Data Reports, No. 28 (Glaciology).))

Naruse, R. 1978. Surface flow and strain of the ice sheet measured by a triangulation chain in Mizuho Plateau. (In Ishida, T., ed. Glaciological studies in Mizuho Plateau, East Antarctica, 1969-1975. Tokyo, National Institute of Polar Research, p. 198-226. (Memoirs of National Institute of Polar Research. Special Issue No. 7.))

Naruse, R., and Shimizu, H. 1978. Flow line of the ice sheet over Mizuho Plateau. (In Ishida, T., ed. Glaciological studies in Mizuho Plateau, East Antarctica, 1969-1975. Tokyo, National Institute of Polar Research, p. 227-34. (Memoirs of National Institute of Polar Research. Special Issue No. 7.))

Naruse, R., and Yokoyama, K. I975. Position, elevation, and ice thickness of stations. (In Naruse, R., ed. Glaciological research program in Mizuho Plateau-west Enderby Land, East Antartica. Pt. 3, 1973-1974. Tokyo, National Institute of Polar Research, p. 7-47. (Japanese Antarctic Research Expedition. JARE Data Reports, No. 28 (Glaciology).))

Naruse, R., and others. 1972. Installation of a triangulation chain and a traverse survey line on the ice sheet in the Mizuho Plateau - west Enderby Land area, East Antarctica, 1969-1970, [by] R. Naruse, A. Yoshimura, and H. Shimizu. (In Ishida, T., ed. Glaciological research program in Mizuho Plateau-west Enderby Land. Pt. I, I9691971. Tokyo, National Institute of Polar Research, p. I I I-31. (Japanese Antarctic Research Expedition. JARE Data Reports, No. 17 (Glaciology).))

Nye, J. F. 1975. Deducing thickness changes of an ice sheet from radio-echo and other measurements. Fournal of Glaciology, Vol. 14, No. 70, p. 49-56.

Shimizu, H. 1978. Outline of the studies of the glaciological research program in Mizuho Plateau, East Antarctica, 1969-1975. (In Ishida, T., ed. Glaciological studies in Mizuho Plateau, East Antarctica, 1969-1975. Tokyo, National Institute of Polar Research, p. I-13. (Memoirs of National Institute of Polar Research. Special Issue No. 7.)) 
Shimizu, H., and others. 1972. Position of stations, surface elevation and thickness of the ice sheet, and snow temperature at ro $\mathrm{m}$ depth in the Mizuho Plateau-west Enderby Land area, East Antarctica, 1969-1971, [by] H. Shimizu, R. Naruse, K. Omoto, and A. Yoshimura. (In Ishida, T., ed. Glaciological research program in Mizuho Plateau-west Enderby Land. Pt. I, 1969-1971. Tokyo, National Institute of Polar Research, p. $12-37$. (Japanese Antarctic Research Expedition. JARE Data Reports, No. 17 (Glaciology).))

Shimizu, H., and others. 1978[a]. Glaciological aspects and mass budget of the ice sheet in Mizuho Plateau, [by] H. Shimizu, O. Watanabe, S. Kobayashi, T. Yamada, R. Naruse, and Y. Ageta. (In Ishida, T., ed. Glaciological studies in Mizuho Plateau, East Antarctica, 1969-1975. Tokyo, National Institute of Polar Research, p. 264-74. (Memoirs of National Institute of Polar Research. Special Issue No. 7.))

Shimizu, H., and others. $1978[\mathrm{~b}]$. Morphological feature of the ice sheet in Mizuho Plateau, [by] H. Shimizu, A. Yoshimura, R. Naruse, and K. Yokoyama. (In Ishida, T., ed. Glaciological studies in Mizuho Plateau, East Antarctica, 1969-1975. Tokyo, National Institute of Polar Research, p. 14-25. (Memoirs of National Institute of Polar Research. Special Issue No. 7.))

Shiraishi, K., and others. 1976. Collection of Yamato meteorites, Antarctica, in December 1973, [by] K. Shiraishi, R. Naruse, and K. Kusunoki. Nankyoku Shiryō: Antarctic Record, [No.] 55, p. 49-6o.

Thomas, R. H. 1976. Thickening of the Ross Ice Shelf and equilibrium state of the West Antarctic ice sheet. Nature, Vol. 259, No. 5540, p. 180-83.

Watanabe, O. 1975. Density and hardness of snow in Mizuho Plateau-west Enderby Land in 1970-1971. (In Shimizu, H., ed. Glaciological research program in Mizuho Plateau-west Enderby Land, East Antarctica. Pt. 2, 1969-1973. Tokyo, National Institute of Polar Research, p. 187-235. (Japanese Antarctic Research Expedition. JARE Data Reports, No. 27 (Glaciology).))

Weertman, J. 1976. Glaciology's grand unsolved problem. Nature, Vol. 26o, No. 5549, p. $284-86$.

Whillans, I. M. 1973. State of equilibrium of the West Antarctic inland ice sheet. Science, Vol. I82, No. 41 I I, p. $476-79$.

Whillans, I. M. I976. Radio-echo layers and the recent stability of the West Antarctic ice sheet. Nature, Vol. 264, No. $55^{82}$, p. $152-55$.

Whillans, I. M. I977. The equation of continuity and its application to the ice sheet near "Byrd" Station, Antarctica. Journal of Glaciology, Vol. 18, No. 80, p. 359-71.

Yamada, T., and Watanabe, O. 1978. Estimation of mass input in the Shirase and the Sôya drainage basins in Mizuho Plateau. (In Ishida, T., ed. Glaciological studies in Mizuho Plateau, East Antarctica, 1969-1975. Tokyo, National Institute of Polar Research, p. I82-97. (Memoirs of National Institute of Polar Research. Special Issue No. 7.))

Yanai, K. 1978. Yamato-74 meteorites collection, Antarctica, from November to December 1974. (In Nagata, T., ed. Proceedings of the second Symposium on Yamato Meteorites. Tokyo, National Institute of Polar Research, p. I-37. (Memoirs of National Institute of Polar Research. Special Issue No. 8.))

Yokoyama, K. 1975. Net accumulation by stake measurements. (In Naruse, R., ed. Glaciological research program in Mizuho Plateau-west Enderby Land, East Antartica. Pt. 3, 1973-1974. Tokyo, National Institute of Polar Research, p. 62-82. (Japanese Antarctic Research Expedition. JARE Data Reports, No. 28 (Glaciology).))

Yoshida, M., and Yoshimura, A. 1972. Gravimetric survey in the Mizuho Plateau-west Enderby Land area, East Antarctica, 1969-1971. (In Ishida, T., ed. Glaciological research program in Mizuho Plateau-west Enderby Land. Pt. I, 1969-197I. Tokyo, National Institute of Polar Research, p. 168-203. Japanese Antarctic Research Expedition. JARE Data Reports, No. I 7 (Glaciology).))

Yoshida, M., and others. 1971. Discovery of meteorites near Yamato Mountains, East Antarctica, [by] M. Yoshida, H. Ando, K. Omoto, R. Naruse, and Y. Ageta. Nankyoku Shiryō: Antarctic Record, [No.] 39, p. 62-65.

\section{DISGUSSION}

I. M. Whillans: Is it possible that the surface lowering could be due to more rapid firn densification now than in the recent past?

R. NARUSE: I think not. The thinning rate $h$ in Mae (I 979) excluded the amount of the surface lowering due to the densification of the upper firn layers. I calculated the densification-rate by using the equation of non-Newtonian densification of snow derived by $\mathrm{H}$. Bader. The amount of the surface lowering obtained was 0.1 to $0.2 \mathrm{~m} \mathrm{a}^{-1}$. But it is an approximate value because the data of the density profile used were those at Mizuho Station, which was located I 50-200 $\mathrm{km}$ from the surveyed region of the triangulation chain.

T. J. Hughes: A good companion study to your transverse strain network would be construction of a strain network along your central flow line. Do you plan to do that?

NARUSE: We think that a strain network study along the central flow line is important, and we want to carry out such a study in the future.

\section{REFERENCE}

Mae, S. 1979. The basal sliding of a thinning ice sheet, Mizuho Plateau, East Antarctica. Fournal of Glaciology, Vol. 24, No. 9o, p. 53-61. 